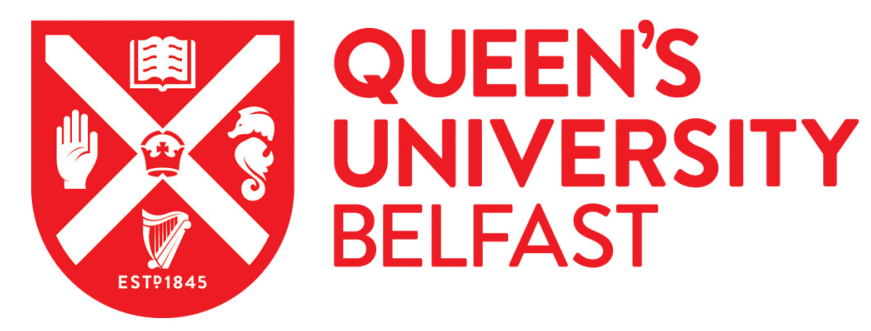

\title{
The role of Lean at the interface with between operations management and applied services within a large aerospace organisation: a boundary spanning perspective
}

McAdam, R., Galbraith, B., Miller, K., Moffett, S., \& McAdam, M. (2016). The role of Lean at the interface with between operations management and applied services within a large aerospace organisation: a boundary spanning perspective. Production Planning \& Control: The Management of Operations, 27(15), 1298-1311. https://doi.org/10.1080/09537287.2016.1221158

\section{Published in:}

Production Planning \& Control: The Management of Operations

\section{Document Version:}

Peer reviewed version

Queen's University Belfast - Research Portal:

Link to publication record in Queen's University Belfast Research Portal

\author{
Publisher rights \\ (C) 2016 Informa UK Limited, trading as Taylor \& Francis Group \\ This is an Accepted Manuscript of an article published by Taylor \& Francis in Production Planning and Control on 19 Aug 2016 , available \\ online: http://www.tandfonline.com/doi/full/10.1080/09537287.2016.1221158
}

\section{General rights}

Copyright for the publications made accessible via the Queen's University Belfast Research Portal is retained by the author(s) and / or other copyright owners and it is a condition of accessing these publications that users recognise and abide by the legal requirements associated with these rights.

Take down policy

The Research Portal is Queen's institutional repository that provides access to Queen's research output. Every effort has been made to ensure that content in the Research Portal does not infringe any person's rights, or applicable UK laws. If you discover content in the Research Portal that you believe breaches copyright or violates any law, please contact openaccess@qub.ac.uk. 
The role of Lean at the interface with between Operations Management and Applied Services within a large aerospace organisation: a boundary spanning perspective

\author{
Authors \\ Professor Rodney McAdam \\ Ulster Business School \\ University of Ulster \\ Jordanstown \\ Belfast, UK BT370QB \\ r.mcadam@ulster.ac.uk \\ Dr Brendan Galbraith \\ Senior Lecturer \\ University of Ulster, Ulster Business school \\ Jordanstown \\ Belfast \\ Belfast, UK \\ b.galbraith@ulster.ac.uk \\ Dr Kristel Miller \\ Lecturer \\ Queens University Belfast, Management \\ Riddel Hall \\ Belfast \\ Belfast, USA \\ kristel.miller@qub.ac.uk \\ Dr Sandra Moffett \\ University of Ulster, \\ Ulster Business school \\ Jordanstown \\ Belfast, UK \\ Sm.moffett@ulster.ac.uk \\ Professor Maura McAdam \\ Dublin City University \\ Dublin, IE 9 \\ Maura.mcadam@dcu.ie
}




\section{Abstract}

Increased complexity in large design and manufacturing organisations require improvements at the Operations Management (OM) - Applied Service (AS) interface areas to improve project effectiveness. The aim of this paper is explore the role of Lean in improving the longitudinal efficiency of the OM-AS interface within a large aerospace organisation using Lean principles and boundary spanning theory. The methodology was an exploratory longitudinal case approach including exploratory interviews ( $\mathrm{n}=21)$, focus groups $(\mathrm{n}=2)$, facilitated actionresearch workshops $(\mathrm{n}=2)$ and two trials or experiments using longitudinal data involving both OM and AS personnel working at the interface. The findings draw upon Lean principles and boundary spanning theory to guide and interpret the findings. It was found that misinterpretation, and forced implementation, of OM-based Lean terminology and practice in the OM-AS interface space led to delays and misplaced resources. Rather both OM and AS staff were challenged to develop a cross boundary understanding of Lean-based boundary (knowledge) objects in interpreting $\mathrm{OM}$ requests. The longitudinal findings from the experiments showed that the development of Lean Performance measurements and lean Value Stream constructs was more successful when these Lean constructs were treated as boundary (knowledge) objects requiring transformation over time to orchestrate improved effectiveness and in leading to consistent terminology and understanding between the OM-AS boundary spanning team.

Keywords: Lean; Operations Management; Applied Service; Boundary Spanning; Aerospace; Case Study. 


\section{Introduction}

This paper focuses on the application of Lean at the interface between Operations Management (OM) and Applied Services (AS) within large design and manufacturing organisations. AS in this context refers to those supporting Information Technology services which support the organisation’s main operations activities (Arlbjørn and Freytag, 2013, Gibbons et al, 2012). Many large design and manufacturing organisations, in seeking to respond to global market challenges are reliant on a complex combination of internal Operations Management and Service Operations Management processes (Bortolotti and Romano, 2012; Alsmadi et al, 2012). Lean principles and lean performance measurements (Lean PMs) have been extensively used in this context in seeking to facilitate such interfaces (Staats et al, 2011; Liker and Morgan, 2006). While there is considerable literature on the development and application of Lean in OM environments, there has been much less research into the OM - AS interfaces within such organisations (Arlbjørn and Freytag, 2013, Gibbons et al, 2012). Riezebos et al (2009) have suggested that the OM - AS interface involving I.T. service delivery to aid design and manufacturing product realization activities have become increasingly important and integral to the success of operations when complex operations are involved, and hence is the subject of the paper.

The target organisation was a large aerospace-based case study which was five years into a major Lean-based transformation initiative (called the Lean Achieving Excellence System, LAES). Here, the design and manufacture of new aircraft programmes was divided into work packages and distributed to a complex integrated network of international partners and suppliers. Information Technology (I.T.) in the form of AS provision played a key role in enabling this integration through its interface with OM. Considerable success in shortening 
cycle times, reducing waste and improving quality had been achieved in the Case organization using Lean and Balanced Scorecards (BSCs) based performance measurement across the design and manufacturing operations. However there was less progress in applying Lean to the interface between OM and AS. The lack of progress led to questioning of the efficacy of Lean is such an interface space or environment as noted by Maleyeff (2006) and Parry et al (2010) that emphasised the need for further research to imove understanding of how to adapt Lean terminology and practice to these circumstances.

Similar to the OM personnel, the AS team were under pressure to improve the efficiency of their provision and to show value for money based on OM demand-pull targets (i.e. targets set by OM that necessitate fulfillment by AS), and hence to avoid being outsourced. There was pressure on the AS team to adopt OM-based Lean PMs in line with the production-based LAES approach which had demonstrated success in design and manufacturing areas as suggested by Liker (2004) and Staats et al (2011). This approach, as part of the LAES system, had achieved, as referred to by Suchman (1995), substantial organizational legitimacy and normalcy. Thus, there was a prevailing view that existing Lean approaches and terminology could be readily translated to the OM - AS interface and other service-based support areas. However, Alsmadi et al (2012) suggests that this approach fails to distinguish between production operations and service operations leading to suboptimal structure and processing within AS-type areas which ultimately limit the effectiveness of the OM - AS interface and which requires further research. Thus, there is a need to take a unique perspective on Lean in the OM-AS interface space rather than simply relying on production-based Lean principles and Lean PMs. This approach necessitated or motivated revisiting underpinning Lean principles linked to boundary spanning theory as suggested Gasson (2006) and Levina and Vaast (2005). 
Overall, the aim of this paper is explore the role of Lean in improving the longitudinal efficiency of the OM-AS interface within a large aerospace organisation using Lean principles and boundary spanning theory. The paper is structured as follow. A brief literature review in section 2 covers Lean theory and its emergence from manufacturing environments, applications within an OM - AS interface and the development of a conceptual model and research questions to frame the research. In section 3, the research methodology is described, followed by section 4 which describes the Case organisation and the OM - AS team. Next, the results are shown followed by the discussion in section 6 . Finally in section 7 conclusions and recommendations are given.

\section{Literature}

\subsection{Lean origin and principles}

Lean emerged in the 1990s to describe the production processes used by Toyota since the 1950s and refers to the use of less space, time, manpower and material than traditional production processes (Martinez-Jirado and Moyano-Fuentes, 2014; Staats et al, 2011; Radnor and Johnston, 2013). A typical definition is that of Wang et al (2012, p5): “Lean is defined as the perfection pursued by the elimination of waste, coupled with the insertion of practices that contribute to cost reduction and schedule while improving performance of products, processes and organisation as a whole." Consistent with this type of definition a key set of overarching Lean principles have emerged in the literature (Staats et al, 2011; Arlbjorn and Freytag et al, 2013; Suarez-Barraza et al, 2012), from which a large number of enabling tools and techniques have been developed to implement these principles, initially primarily in manufacturing organisations focussing on waste elimination (Lyons et al, 2015; Alsmadi et al, 2012; Arlbjørn et al, 2011). These principles as stated by Womack and Jones (1996), Hines et al (2004) and Mayalef (2006) are: 
1. Specify value. Value is defined by the ultimate customer. It is specified in terms of satisfying customers' needs by providing products and/or services at a competitive price and lead time.

2. Identify the value stream. The set of all of the actions required to bring a product through problem-solving, information management, and physical transformation tasks. Here, value refers to the nature of activity being carried out. The value stream is the set of actions that transform a product or service.

3. Make the value flow. By reducing cycle times and batch sizes to the absolute minimum, ensuring each operation is visible and defined, to eliminate possible stoppages in the production process.

4. Let the customer pull. Processes or products are to be produced and delivered on-demand from the customers.

5. Pursue perfection. A culture of embedding the Lean principles is adopted.

Within Lean there is a primary focus on value and cost reduction (Lyons et al, 2015). As shown by Womack and Jones (1996), in the first principle, value is ultimately perceived or attributed by the customer. Thus, value is equated with giving more customer satisfaction than competitors (Seddon, 2005). In this principle the focus is not on cost reduction but rather identifying what is value to the customer (either internal or end customer (Hines et al, 2004)

Building on this concept of value the second Lean principle develops the concept of the value stream which is used as a transformative process within Lean (Arlbjorn and Freytag, 2013; Staats et al, 2011). Here it is assumed that the customer value proposition ultimately requires a set of value adding actions to produce a valuable product or service to the customer. Seddon (2005), Parry et al (2010) and Marr suggest that Lean Value Stream development requires working backwards from the customer or "outside in" to assess how a customer can "pull” 
value from the organisation's activities system. They suggest that the alternative approach of working forward from management's perception of customer needs is likely to introduce waste due to misalignment. Similarly, Marr and Glenn (2004) state that performance measures associated with the Value Stream should not be confused with operational measures and refer to call centre measures such as length of time taken to answer calls, percentage of calls abandoned by callers, and the average time a call centre operator stays with a customer. They, along with Seddon (2008) call these "push" performance measures which may not have any value in satisfying customers.

The third Lean principle introduces the concept of waste within Lean. 'Make the value flow' examines each of the activities within the Lean Value Stream continuously to ensure that wasteful use of resources have not occurred (i.e. non-value adding activity). Typical manufacturing wastes include excessive cycle times and inventory costs. The majority of Lean tools and techniques are focused on the activity of waste classification and reduction using value adding classifications. Thus the underlying Lean principles clearly differentiate between value and waste and between value adding and that of waste reduction or minimisation as suggested by Lyons et al (2015).

The fourth Lean principle essentially incorporates principles 2 and 3 in that establishing Lean Value Streams of value adding activities and in reducing wasteful activity; the prime determiner must be the customer. This approach implies that knowledge of the customer and the development of customer value propositions are necessary, rather than relying on organisational push factors (Biege et al, 2012). 
The fifth Lean principle suggests that Lean is not a one-off or discretised set of activities. Rather it is a continual quest within an organisation where there is an assumed atrophy of customer value satisfaction coupled with waste inclusion over time if no Lean interventions are made (Maleyeff, 2006; Parry et al, 2010). This approach suggests that Lean should become part of the culture of an organisation (Martinez-Jurado and Moyano-Fuentes, 2014; Jaaskelainen et al, 2012).

\subsection{Lean in an OM-AS interface}

Problems associated with the interface between OM and AS environments involving the direct transfer of Lean terms from OM include the misinterpretation of terminology (Biege et al, 2012 and Jaaskelainen et al, 2012), lack of a tangible product (Liker and Morgan, 2006) and the higher degree of variability of demand relating to service environments (Arlbjørn and Freytag, 2013; Seddon, 2005). Bowen and Youngdahl (1998) suggest that Lean can act as a mediating mechanism between the boundary spanning interface of OM - AS provided these issues are addressed. Hines et al (2004), consistent with Biege et al (2012), highlighted the need to address Lean’s applicability outside a manufacturing environment in dealing with variability and its limited consideration of people related issues in OM - AS interfaces. The literature shows that there has been considerably less research in the application of Lean in OM - AS interfaces in comparison to that of product-based activities such as OM (Arlbjørn et al, 2011 and Radnor and Johnston, 2013; Del Palacio et al, 2011; Piercy and Rich, 2009). Lean in OM

- AS has been identified as a key area for further research and development, typically within large organisations which is the focus of this paper (e.g. Johnston et al, 2012; Liker and Morgan, 2006). 
In the literature four key characteristics of OM - AS interfaces have emerged that separate them from a purely product focus (Biege et al, 2012; Alsmadi et al, 2012). Inseparability: The customer (production departments, people and processes) and supplier (service department, people and processes) are interactively fused within the overall OM-AS space and processes. Heterogeneity: OM-AS interface activities may vary due to considerably changing customer requirements in contrast to mass production. Intangibility and Perishability: OM-AS activities are mainly intangible and therefore cannot be stored i.e. they are produced as needed rather than stored for future use. Jaaskelainen et al (2012) suggest that these differentiating characteristics, consistent with a focus on value-in-use rather than value-in-exchange, create considerable challenges to developing Lean in the OM - AS interface where simply translating production-based Lean PM terminology and practices will lead to confusion and suboptimising of OM - AS interface effectiveness.

Biege et al (2012) suggest that the Lean product based term of 'demand' requires reinterpretation in an OM-AS context due to the increased variation in demand and the difficulty in addressing intangibles and in interpreting 'Failure Demand'. Seddon (2005, 2008) developed the performance measure of Failure-Demand that can be applied in an OM - AS interface context. Seddon (2005) suggested that Lean principles covering Lean Value Streaming and waste elimination inherently cover Failure-Demand. He defined FailureDemand as a concept, which provides insight into the inability of the Customer experience (design) to provide for a Customer's desired outcome(s). Failure-Demand is viewed as not providing all of what the customer requires and as such, constitutes waste in the system. This definition of waste is in addition to the more overt wastes identified through the Lean Value Stream, such as of excessive inventories and cycle times (Lyons et al, 2015). Thus, Marr and Parry (2004) suggest Failure-Demand relates to a product or service that does not meet the 
customers' needs and expectations and hence its production or realisation generates additional work or activity that is non value added or wasteful. It is the opposite of value demand, which are the customers' requirements."

Seddon (2008) concludes that the concept of Failure-Demand can be used to explain the level of extra work to be done as a consequence of failures of the organisation to align with customer requirements and also as a concept that contributes to an OM-AS context. For example, Marr and Parry (2004) in their study of Fujitsi call centres and their interface with OM requirements found that $40-90 \%$ of incoming service requests were entirely preventable (i.e. no value created). Seddon (2005) therefore concluded that in Lean the principle of understanding demand is needed as a corollary to that of understanding waste, within the Lean Value Stream mapping process.

Robinson and Morley (2006) suggest that there is a focus on quantitative production-orientated Lean PMs in AS contexts, encouraged by software vendors, who offer the continually increasing ability to log and manage quantitative elements of service operations from an internal perspective. AS managers find this approach appealing as the Lean PMs produced by the software can be used by them to satisfy senior management and provide a basis for comparison of performance with other support service organisations using the same software (Robinson and Morley, 2006). They call for a shift away from solely relying on these internal quantitative measures and suggest the need for alternative Lean PMs for OM-AS interface areas.

\subsection{Conceptual development and research questions}

In addition to the Lean principles as already discussed we also draw upon boundary spanning interface theory to conceptualise OM-AS interface as an inter-organisational boundary as 
suggested by Carlile (2002, 2004) and Gasson (2006). In seeking to conceptualise the interface across the OM-AS boundary we draw upon boundary spanning theory focussing on interfaces as developed by Carlile (2002, 2004). Greve and Salaff (2003) and Peltier and Naidu (2012) who suggest that boundary spanning such as in the OM-AS interface involve network is conceptualised a series of internal and external boundary spanning knowledge flows between actors, consistent with Open Innovation theory (Chesbrough, 2011). These boundaries are seen as being linked by common boundary objects or knowledge based objects (KOs) (Wang, 2012, Swan et al, 2007). Each of the OM and AS actors working in the interface space are seen as influencing the boundary spanning KOs to a greater or lesser extent as joint project requirements are progressed in a longitudinal manner (McGivern and Dopson, 2010; Carlile, 2004). The boundaries spanned by the KOs are seen as being "pragmatic" or knowledge in practice based (Swan et al, 2007; Carlile, 2004, 2002) i.e. where different interpretations from OM and AS actors can reach an agreed or consensual position on a set of actions; this approach supports the idea of the boundary spanning $\mathrm{KO}$ being interpretable for different actors with a need for a consensual position to progress the project (Swan et al, 2007). The implication is that KOs must be malleable or have some degree of developmental capacity on an intangibletangible continuum as the joint $\mathrm{OM}$ - AS project network progresses towards completion (Krafft et al, 2011, Hult, 2011). Hence McGivern and Dopson (2010) suggest that KOs should be carefully chosen from the start to have a high degree of "interpretive flexibility" where different actors can have scope to influence the $\mathrm{KO}$ and their subsequent development from an intangible state. Hult (2011) suggest that that the transformation of the KOs should be part of value creation in the interface with an emphasis on process development rather than functionalism. Hence, in this context we suggest that the KOs include Lean PM sets and the Lean Value Stream maps that are jointly influenced and developed over time by both the OM and AS actors working in the interface space. These lean boundary (knowledge) objects meet 
the KO definition requirements (McGivern and Dopson, 2010) as being malleable and transformative in nature. As the joint project progresses Kos (i.e. Lean PM sets and Value Stream maps) become more established or tangible (Spithoven et al, 2010). The formulation of KOs and conflicts of interest require careful management of the interface to ensure that interpretable KOs are developed consensually and to avoid dominance by one particular group (McGivern and Dopson, 2010; Swan et al, 2007; Wang, 2012; Vowles et al, 2011). For example, OM actors may attempt to overly direct the KO transformation based on prevailing timescales and the need for tangible output based on their performance measures. Early in the KO transformation process there is likely to be high levels of cognitive distance between the $\mathrm{OM}$ and AS actors who represent differing epistemic communities (i.e. Knowledge bases involving production and Information systems respectively) (de Jong and Freel, 2010). McGivern and Dopson (2010) suggest that when the KOs are relatively less structured or insipient there is an opportunity for the joint team (OM - AS) to build meaningful consensus. Here the knowledge based (KBs) of the production and information systems (Hellstrom et al, 2001) and the KOs are based on knowledge which has high levels of lucidity, abstraction, and indererminability (as reflected in insipient versions of Lean PMs and Lean Value Streams). Thus initially there is likely to be higher levels of what Carlile (2004) refers to as syntactic knowledge sharing (e.g. establishing common language portfolios in relation to KOs between $\mathrm{OM}$ and AS actors using the KOs of lean PMs and Lean Value Streams) and semantic knowledge sharing (developing shared meanings for insipient KOs) with relatively high levels of "amplified uncertainty" (Baglieri et al, 2012). The Lean KOs are seen as becoming more defined at the project progresses with jointly agreed Lean PM sets and Lean Value Streams being established and readily transferable amongst all of the actors involved (Letti et al, 2008). Thus we suggest that Lean KOs can be used to orchestrate the progression of projects at the 
OM-AS interface. McGivern and Dopson (2012) suggest that the KO transformation process represents an ‘unfolding ontology’ as OM-AS projects are progresses.

The boundary theory conceptualisation views the interface and its knowledge bases and KOs as a pragmatic boundary and a crucible or "space of representation” (McGivern and Dopson, 2010, Carlile, 2004) which is by definition a highly contested space until consensus is reached and legitimacy established for all of the partners (Levina and Vaast, xxx). Gasson (xxxx) refers to this development as a cross boundary sense making process. Thus we view the OM - AS interface as a unit of analysis for the current study. Carlile describes this interface space as being situated, localised and purposive. Hence in the current study we focus on the contextual conditions influencing this OM - AS interface space which is "embedded in practice” (Carlile, 2004: 446). Levina and Vaast (2005) suggest the need for more research on interfaces to determine contextual factors which influence their successful development

Based on the brief review of the literature in relation to the emergence of the principles of Lean and the boundary spanning theorisation and the initial exploratory interviews relating to the case organisation (Phase 1 of the research methodology in section 3.0, Figure 3) a contextual framework was developed (Figure 1) to show the interface challenges facing an AS team, consistent with Alsmadi et al's (2012, p 393) statement that “Lean needs to be distilled and tailored for each context”. 


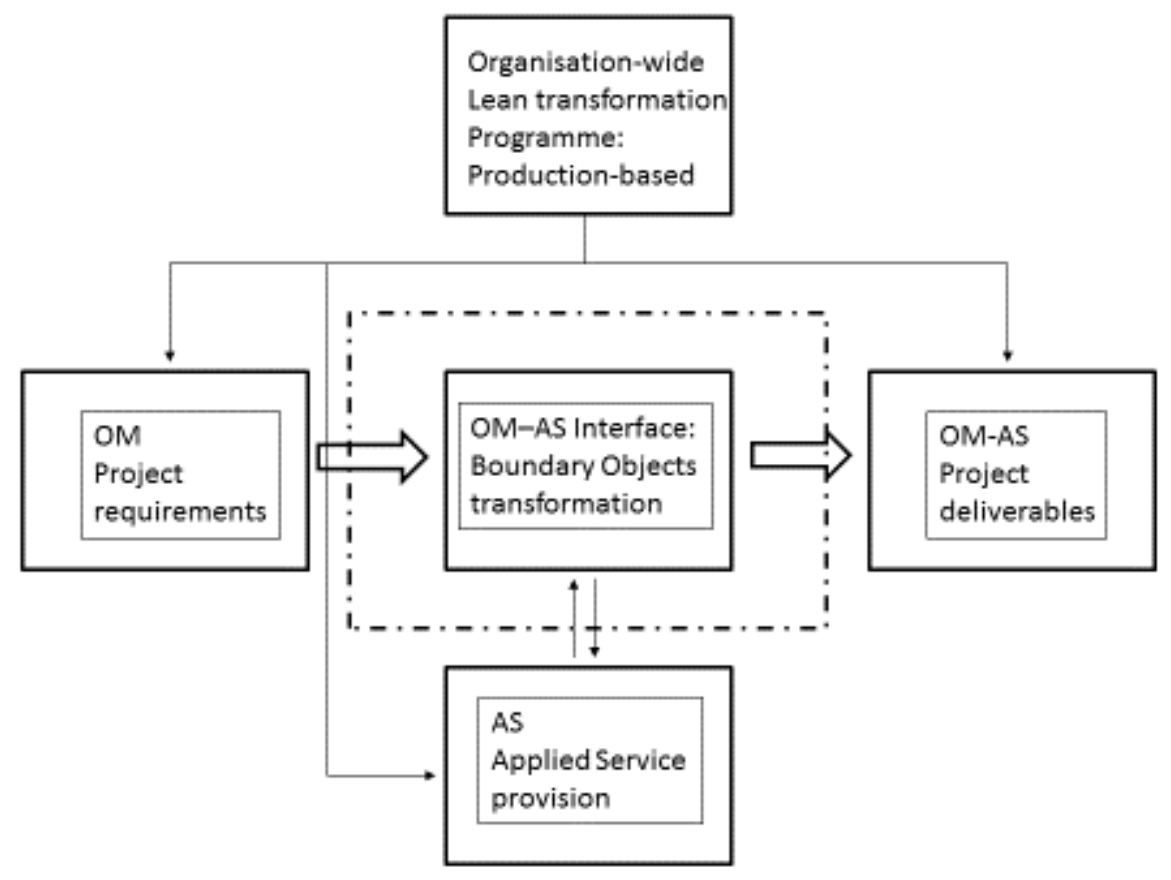

Figure 1 - Contextual Framework

The first conceptual framework of Figure 1 shows the main flow of activity within the Case organisation. Here the organisations $\mathrm{OM}$ (OM project requirements) are seen as progressing an aerospace project (pressurised fuselage components requiring AS inputs in the current study) Next, the project is seen as requiring AS inputs through the OM-AS interface described as the OM-AS Boundary Objects transformation i.e. where the OM and AS personnel interact to progress the project. Following this transformation as shown on the right hand side of the project the project deliverables are achieved. Figure 1 also shows that the AS (AS applied service provisions also impact the OM-AS interface and that the organisational wide production-based Lean transformation programme (LAES) which was underway across the company impacts on both the OM and AS departments albeit from a standardised production perspective. Building on Figure 1 and in line with the aim of the paper we further focus on and conceptualise the OM-AS interface (the dotted line element of Figure 1) as shown in Figure 2. 


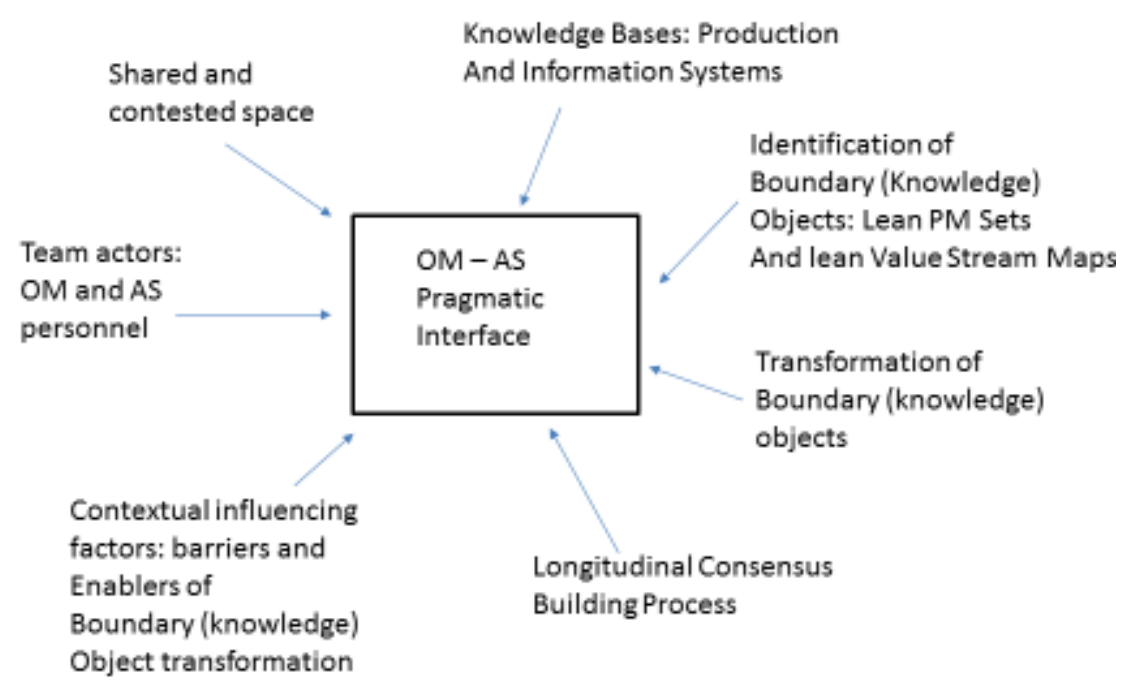

Figure 2 - Lean conceptualisation of the OM-AS interface space

Here the OM-AS interface is seen as involving a number of influences as discussed above as shown in Figure 2. The interface is viewed as a pragmatic cross-boundary where transformation takes place as suggested by McGivern and Dopson (2010) and Carlile (2004). This transformation involves identification and transformation of the boundary spanning objects (KOs - Lean PM sets and Lean Value streams in the current study) which are seen as being achieved through a longitudinal consensus building process. Figure 2 also shows that the interface space will be influenced by a range of contextual factors (including barriers and enablers in relation to the knowledge object transformation

Based on the conceptual framework representations of Figures 1 and 2, the supporting literature and initial exploratory interviews three research questions have been developed to guide the empirical work. First, the AS group had conflicting Lean influences. Their activities and outputs were all service based as suggested by Arlbjørn and Freytag (2013) and Gibbons et al 
(2012). However, the requirements of the OM personnel (Figure 1, construct 2) were couched in product-based Lean PMs leading to what McGivern and Dopson (2010) refer to as distinct initial knowledge bases or epistemic communities. Moreover, there was an organisational-wide promulgation of product based Lean PMs applied to all departments including production and applied services (Figure 1). Hence there was a need to explore how OM - AS actors perceived and interpreted these Lean PMs and demands, within the OM-AS interface space as suggested by Arlbjorn and Freytag (2013) and Radnor and Johnston (2013). Hence the first research question is as follows.

RQ1: How do OM and AS team members interpret Lean PMs in addressing OM project requests within the OM-AS interface space?

Second, based on the OM-AS interface as a pragmatic or in practice space, the overall process of transforming interface Boundary (knowledge) objects interaction is the main practice influenced by Lean in terms of Lean value stream maps and Lean PM sets as suggested by Staats et al (2013) in the absence of a tangible product. Moreover Coughlan and Coghlan, (2002) and subsequent studies by Suarez-Barraza et al, 2012), Maleyeff (2006) and Gibbons et al (2012) suggest the need for more longitudinal Lean research i.e. action-based research taken over a specified time period. Here, any improvements to flow and efficiency must be verified in practice over time and reflect the progressive understanding of the OM and AS actors (as determined in RQ1) rather than simply taking views at a single point in time. Hence the second research question is:

RQ2: Based on the levels of perception and understanding determined from RQ1, how can knowledge objects (Lean PM sets and lean Value Stream maps) be used and transformed to improve the OM-AS interface effectiveness in leading to project outputs over time? 
As already noted a key element within Lean PM in a OM-AS interface space is that of FailureDemand which Seddon (2005) suggests should be applied to support the customer (operations requesters) pull in reducing waste in the OM-AS KO transformation process through lack of addressing customer requirements. Similarly in relation to RQ3, Jaaskelainen et al (2012) and Gibbons et al (2012) suggest the need for action based research studies that show any longitudinal improvements (to boundary spanning Kos in the current context) to value and waste from applying Lean Failure-Demand performance measures. They suggest that such studies must be verified in practice and reflect the consensual understanding of both OM and AS staff (as determined in RQ1 and RQ2). Hence the third research question is:

RQ3: What longitudinal transformation of the Lean PM sets and Lean Value Stream (KOs) can be achieved introducing Lean PMs based on Lean Failure-Demand as part of the Lean Value Stream?

\section{Research Methodology}

An exploratory action research case study approach was used (e.g. Coughlan and Coghlan, 2002, Suarez-Barraza et al, 2012, Maleyeff, 2006 and Gibbons et al, 2012) based on an OMAS interface as the unit of analysis within a large multinational aerospace company to address each of the three 'how' and 'what' type research questions as suggested by Eisenhardt (1989), Yin (2011) and Pratt (2009). The exploratory case approach is seen as adding deep, rich data on the contextual and dynamic attributes in the area of study which is viewed as a pragmatic boundary to be explored through practice (Swan et al, 2007; Barratt et al, 2011, Pratt, 2009). Using a priori Lean constructs and boundary spanning theory from the literature, consistent with Eisenhardt (1989) and Barratt et al (2011), a four phase research methodology was adopted for the case study as shown in Figure 3. 


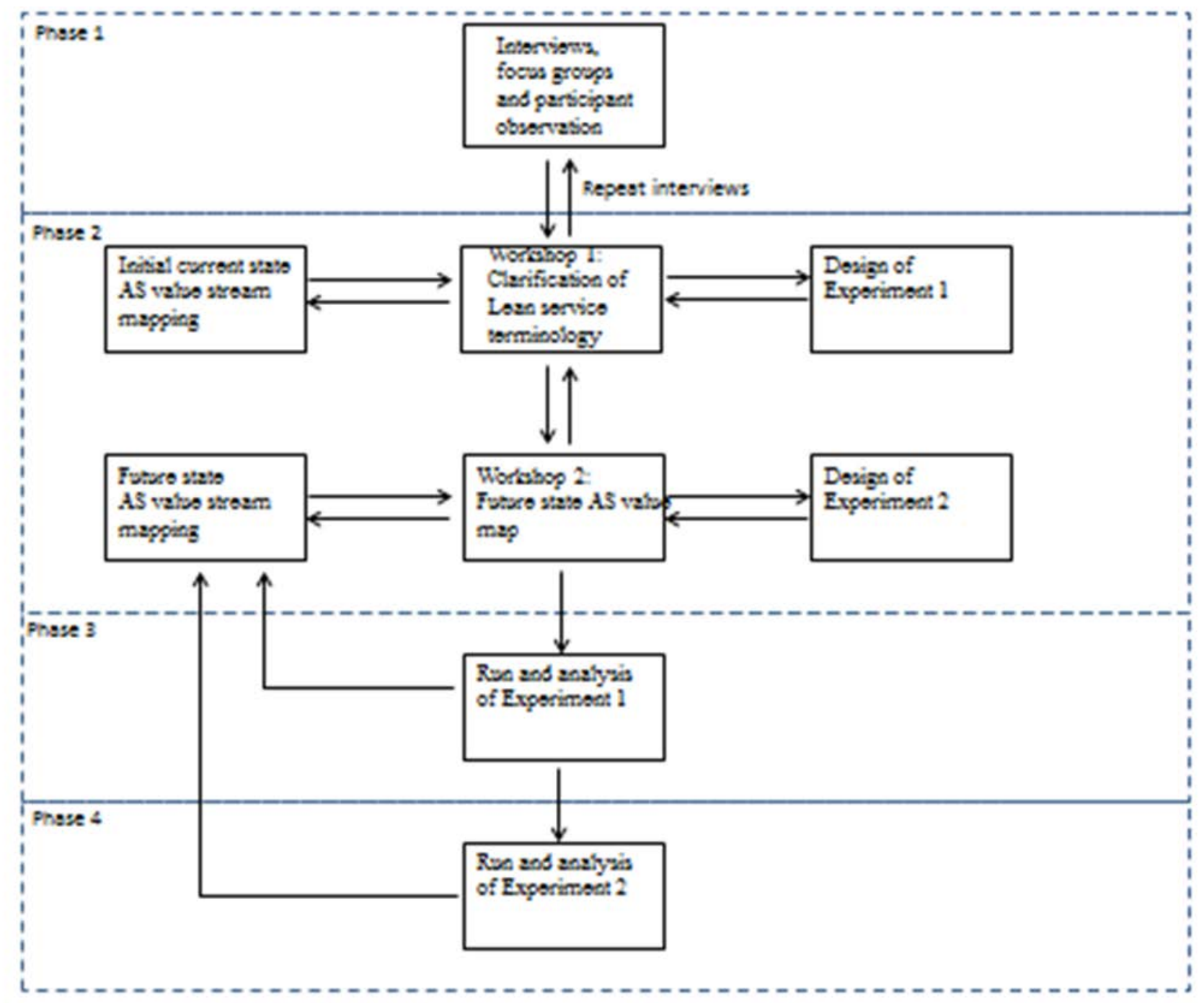

Figure 3 - Four Phase research Methodology

Phase 1 , in addressing RQ1 primarily, involved exploratory interviews ( $\mathrm{n}=21$ ), focus groups $(n=2)$, and participant observation (one of the researchers was a manager within the OM-AS interface team throughout the study period and logged detailed notes), which were used to determine levels of $\mathrm{OM}$ and AS staff understanding and awareness of Lean constructs (including the influence of the production-based LAES programme (Figure 1). Interviewees were selected who has experience of working on projects in the OM-AS interface space over at least a three year timescale. The interviews were semi structured in nature (see Appendix No 1) and were held with a cross section of management and staff from each of the OM-AS sub 
teams. These interviews were recorded, transcribed and coded and the findings were further explored at focus groups ( $\mathrm{n}=2$ ) (cross- section of employees and managers, $n=6$ (two managers and four employees), facilitated by the researchers). The interviewees were managers and technical service specialists within the OM-AS interface. These findings were cross checked with participant observations, as suggested by Yin (2011) from one of the researchers placed within the OM-AS interface team.

In Phase 2 the findings from both the interviews, focus groups and observations were used to design and run two participative workshops in an action research manner (including repeat interviews for points of clarification from phase 1 (Figure 3). These one day workshops each with twenty OM and AS staff with a facilitator used plenary and sub group sessions to further determine key issues of understanding and interpretation of Lean constructs in relation to RQ1. The workshops also involved consensually agreeing the transforming of the boundary (knowledge) objects in forming initial and future state OM-AS Lean PM sets and Lean Value Stream maps and to design experiments in addressing RQ2 and RQ3 (where the word experiments in used in the sense of attempting to demonstrate a set of facts). The objective of the first workshop was to explore and obtain a consensus based understanding of OM-AS Lean PM sets knowledge object based on the interview and focus group findings. It also involved consensually designing the first experiment to address RQ2 and training in the use of Lean tools and techniques to map and validate the knowledge object referred to as the current or asis Lean Value Stream for AS service delivery. The second workshop in phase 2 was used to interactively and consensually develop the knowledge object referred to as the future state Lean Value Stream map. 
In Phase 3 (Figure 3), the first experiment, in relation to RQ2 involved applied customer demands that were used to trial the optimised process i.e. the future state OM-AS Lean Value Stream map from phase 2. A series of actual demands to the OM-AS interface team from OM projects were taken through the entire lifecycle involving evaluation, approval, specification, development, testing and implementation. This first experiment targeted demand and flow within the OM-AS interface. Resources could only be spared to conduct the flow experiment in one of the OM-AS sub-teams (the Main Manufacturing System (MAXIM) sub team) and for a limited number of demands due to organisational pressures and resource limitations.

The fourth phase (Figure 3) involved a further longitudinal experiment (Figure 3), based on RQ3, using failure demand Lean principles (e.g. Seddon, 2005) to focus on the reduction of waste and the possibility of introducing a consensual KO of Lean PMs based on Lean FailureDemand classifications to the future state Lean Value Stream map KO from phase 2 (Figure 3). This approach included waste identification and categorisation in the OM-AS interface context. There was an analysis of a sample of PM-As demand data which was analysed by applying criteria to classify each demand as value added or non-value added, using the Lean definition of value in terms of value to the customer (operations requestors). The sample was typical of the set of requests received on a regular basis. The staff responsible for the OM-AS sub groups was asked to conduct an analysis of the demands that they had received over the period of one month (based on resource availability). This analysis was based on a given set of criteria for the classification of the demands as value added or non-value added, consistent with Biege et al (2012) and Gibbons et al (2012). Demands categorised as non-value added were regarded as 'failure demand.' After consultation between the OM and AS personnel the criteria set for the classification of a demand as non-value added was: 
- A defect in the design or delivery of the application to the user that will result in a recurring issue for the customer;

- A required step within a regular customer process that can only be performed by an I.T. Support resource; and

- Activities that could be automated or control given to the customer to perform.

The findings from Phase 4 were used to make further adjustments to the Kos of the future state AS Lean Value Stream map (Figure 4) and OM-AS Lean PMs.

\section{The Case Organisation and the AS team}

The case organisation within the Group was a design and manufacturing organisation for major aircraft components and is the only company to be involved in all of the Group's aircraft programmes. The organisation has been challenged by the entry of emerging economies into the aerospace industry. These emerging economies such as Mexico and China have government subsidies, lower wages in general and compete strongly for manufacturing work packages. The Group's business strategy was to establish manufacturing plants in these countries to avail of the subsidies and low wages.

The mission statement for the Case organisation: 'To be the supplier of choice for innovative aerospace engineering solutions', challenged the Case organisation management to contribute through the companywide LAES programme (Figure 1) nominally involving all production and service areas and activities. The OM-AS interface role in helping to enable and support the transition to achieve these goals through Lean relates to the current study. The OM-AS team was split into OM-AS sub teams focusing on the main functional areas within the business, i.e. Design Engineering operations, Manufacturing Engineering operations and Shop Floor 
Operations (Table 1). Within each of these OM-AS sub teams there were a number of units, e.g. the MAXIM unit - Supports the Main Manufacturing System (MAXIM); and the Final Assembly Time System (FATS) unit - Supports the Final Assembly Time Sheet system (FATS).

\section{Results}

The Results section addresses the findings in relation to each of the three research questions. The sub sections cover:

- OM and AS staff interpretations the KO of Lean PM sets in addressing OM service requests (covering Phase 1 and primarily RQ1).

- OM-AS provision KO of current and future state value stream mapping and opportunities (covering Phase 2 and primarily RQ2). - Experiment 1 - Flow Experiment (covering Phase 3 and primarily RQ2). - Experiment 2 - Failure-Demand Experiment (covering Phase 4 and primarily RQ3).

\subsection{AS staff interpretations of Lean PMs in addressing OM service requests (covering Phase 1 and primarily RQ1).}

The findings in relation to RQ1 and RQ2 as derived and coded from the interviews and focus groups and as discussed at the first and second workshops (Figure 3) in relation to opportunities to improve the Lean Value Stream are shown in the evidence table (Table 1).

Table 1 about here: Abstracted interview, focus group and workshop 1 findings

\begin{tabular}{|l|c|l|l|}
\hline Key Area. & OM-AS Sub team 1 & OM-AS Sub team 2 & OM-AS Sub team 3 \\
\hline Key Area 1 - & $\begin{array}{r}\text { Across all sub teams: } \\
\text { Operational level: } \\
\begin{array}{l}\text { OM-AS Interface } \\
\text { issues (RQ1) }\end{array}\end{array} \quad \begin{array}{l}\text { Poor past record of service delivery due to lack of a consistent set } \\
\text { of operations-based Lean PMs. }\end{array}$ \\
$\begin{array}{l}\text { Culture of inward IT measurement in AS rather than adopting } \\
\text { joint sets of Lean PMs with OM. }\end{array}$ \\
\hline
\end{tabular}




\begin{tabular}{|c|c|c|c|}
\hline & \multicolumn{3}{|c|}{$\begin{array}{l}\text { - OM rely on simplified operations based Lean PMs e.g. frequency } \\
\text { and duration of operations requests. Lack of standardised } \\
\text { procedures leading to excessive timescales for problem } \\
\text { resolution. } \\
\text { - } \quad \text { Replication of resources due to lack of standardisation for } \\
\text { requests. } \\
\text { - } \quad \text { Large variety of requests with high levels of variability within each } \\
\text { request. }\end{array}$} \\
\hline $\begin{array}{l}\text { Key Area 2- Strategic } \\
\text { level: } \\
\text { AS-OM } \\
\text { Interface issues } \\
\text { (RQ1) }\end{array}$ & \multicolumn{3}{|c|}{$\begin{array}{l}\text { - } \quad \text { Lean PMs translated from operations without reinterpretation } \\
\text { and contextualisation } \\
\text { - } \quad \text { Lack of customer pull Lean PMs } \\
\text { - } \quad \text { Technology rather than service focus } \\
\text { - } \quad \text { The Lean influence of the LAES } \\
\text { - } \quad \text { Lack of staff training, development and incentives to address Lean } \\
\text { PM service interpretation and contextualisation. } \\
\text { - } \quad \text { Lack of senior management understanding of the AS-OM } \\
\text { differences in relation to Lean PMs } \\
\text { - The challenge of tailoring of the Legacy IT systems to meet a } \\
\text { variety of OM customer demands. }\end{array}$} \\
\hline $\begin{array}{l}\text { Key Area } 3 \text { - Specific } \\
\text { OM-AS sub team } \\
\text { issues based AS-OM } \\
\text { Interface issues } \\
\text { (RQ1) }\end{array}$ & $\begin{array}{l}\text {-Poor definition of } \\
\text { scope and } \\
\text { requirements of OM } \\
\text { requests. } \\
\text { - Lack of discussion to } \\
\text { align AS-OM } \\
\text { requirements. } \\
\text {-Lack of business } \\
\text { process identification } \\
\text { in the form of Lean } \\
\text { Value Stream mapping. } \\
\text {-Coping with changing } \\
\text { OM priorities in terms } \\
\text { of resource allocation. } \\
\text {-Reactive change to } \\
\text { OM problems rather } \\
\text { than joint planning and } \\
\text { scheduling. } \\
\text {-Lack of OM-AS proven } \\
\text { Lean toolset leading to } \\
\text { inappropriate } \\
\text { application of product } \\
\text { based lean tools and } \\
\text { Lean PMs. }\end{array}$ & $\begin{array}{l}\text {-Lack of OM-AS sub } \\
\text { team leadership in } \\
\text { Lean PM due to lack of } \\
\text { staff with cross OM-AS } \\
\text { experience. } \\
\text {-Inconclusive OM-AS } \\
\text { performance meetings } \\
\text { due to unclear } \\
\text { accountability. } \\
\text {-Ivory Tower attitude } \\
\text { of professional AS } \\
\text { team based on higher } \\
\text { education levels. } \\
\text {-Excessive } \\
\text { measurement of } \\
\text { readily quantifiable } \\
\text { Lean PMs leading to } \\
\text { box ticking and dealing } \\
\text { with easier problems. } \\
\text { - Excessive } \\
\text { measurement of Lean } \\
\text {-PMs unrelated to } \\
\text { interface } \\
\text { improvement projects } \\
\text { and steps. } \\
\text {-Problems of } \\
\text { ownership between } \\
\text { OM and AS due to lack } \\
\text { of a process structure. }\end{array}$ & $\begin{array}{l}\text {-Lack of use, and } \\
\text { relevance of, } \\
\text { documented } \\
\text { procedures (i.e. not } \\
\text { jointly formulating } \\
\text { OM-AS work plans). } \\
\text {-Lack of team } \\
\text { knowledge } \\
\text { management leading } \\
\text { to replication of } \\
\text { resources and misuse } \\
\text { of specialist resources. } \\
\text {-Lack of focused } \\
\text { training on the OM-AS } \\
\text { interface in developing } \\
\text { Lean PMs. } \\
\text {-Hierarchical sign-off } \\
\text { causing delays without } \\
\text { adding value. } \\
\text {-Established status- } \\
\text { quo } \\
\text { of existing practices } \\
\text { and staff due to long } \\
\text { service records. } \\
\text {-Lack of learning from } \\
\text { past mistakes with a } \\
\text { risk adverse } \\
\text { environment. }\end{array}$ \\
\hline $\begin{array}{l}\text { Key Area } 4-\mathrm{OM}-\mathrm{AS} \\
\text { Sub team issues } \\
\text { based AS }\end{array}$ & $\begin{array}{l}\text {-Number of defects } \\
\text { and rework timescales. } \\
\text {-Process waiting time. }\end{array}$ & $\begin{array}{l}\text {-Extra workflow } \\
\text { requests with } \\
\text { increased variation. }\end{array}$ & $\begin{array}{l}\text {-Lack of understanding } \\
\text { of customer (OM) } \\
\text { requests. }\end{array}$ \\
\hline
\end{tabular}




\begin{tabular}{|c|c|c|c|}
\hline $\begin{array}{l}\text { identification and } \\
\text { interpretation of } \\
\text { waste based Lean } \\
\text { PMs (RQ1) }\end{array}$ & $\begin{array}{l}\text {-Work backlog and } \\
\text { Work In Progress (WIP) } \\
\text { measurement. } \\
\text {-Production line based } \\
\text { measures. } \\
\text {-Interruptions due to } \\
\text { OM emergencies. } \\
\text {-Extra requirements } \\
\text { post initial service } \\
\text { requests. } \\
\text {-Lack of consideration } \\
\text { of waste associated } \\
\text { with Failure-Demand. }\end{array}$ & $\begin{array}{l}\text {-Number and duration } \\
\text { of calls. } \\
\text {-Defect levels. } \\
\text {-Extra processing and } \\
\text { over production } \\
\text { beyond the agreed } \\
\text { specification. } \\
\text {-Lack of prioritisation } \\
\text { of work leading to } \\
\text { misplaced resource } \\
\text { allocation. } \\
\text {-Lack of consideration } \\
\text { of waste associated } \\
\text { with Failure-Demand. }\end{array}$ & $\begin{array}{l}\text {-Inadequate testing } \\
\text { and piloting of } \\
\text { solutions prior to roll } \\
\text { out. } \\
\text {-Extra processing } \\
\text { beyond the } \\
\text { specification. } \\
\text {-Technology push } \\
\text { leading to lack of } \\
\text { customer (OM) } \\
\text { relevance. } \\
\text {-Hierarchical sign off } \\
\text { delays. } \\
\text {-Lack of consideration } \\
\text { of waste associated } \\
\text { with Failure-Demand. }\end{array}$ \\
\hline $\begin{array}{l}\text { Key Area } 5 \text { - Lean } \\
\text { Value Stream } \\
\text { improvement } \\
\text { opportunities across } \\
\text { all OM-AS sub teams } \\
\text { (RQ2) }\end{array}$ & \multicolumn{3}{|c|}{$\begin{array}{l}\text { Across all sub teams: } \\
\text {-Lean PM terminology clarification in an AS context. } \\
\text {-Improved OM Customer needs analysis. } \\
\text {-New set of OM-AS-based Lean PMs } \\
\text {-Increased standardisation of routine OM requests. } \\
\text {-Reduction in the complexity and number of activity steps within the Lean } \\
\text { Value Stream. } \\
\text {-Improved process for resource prioritisation and allocation in the Lean } \\
\text { Value Stream activities. } \\
\text {-Improved tailoring of the legacy IT systems to maintain relevance to OM } \\
\text { requests and to avoid the need to invest in alternative bespoke systems. } \\
\text {-Reduction in excessive cycle times and waiting time with the Lean Value } \\
\text { Stream. } \\
\text {-Reduce hierarchy and interdependence in the Lean Value Stream activity } \\
\text { steps to reduce delays. } \\
\text {-Decreasing reliance on AS technology push in comparison to OM pull. } \\
\text {-Reduced down time due to technical systems failures. }\end{array}$} \\
\hline
\end{tabular}

The evidence table (Table 1) is divided into 5 key areas down the left hand side relating to RQ1 and RQ2. First, in relation to RQ1 the perceptions of the operational and strategic issues relating to the OM-AS interface are shown in Key Areas 1 and 2 (Table 1). Next, in Key Areas 3 and 4 the views of each of the three main OM-AS sub team's relating to these issues are shown along with their perceptions of Lean again in relation to RQ1. Finally in key area 5 areas for improvement to $\mathrm{KO}$ of the Lean Value Stream are identified common to all of the three main OM-AS sub teams in addressing RQ2. 
The AS team has developed the majority of the IT applications as part of the legacy systems used by the Case Organisation with high degrees of customisation for the OM-AS interface. Moreover, in some cases the rights to the original code was purchased by the Case Organisation. The AS staff had an average of twenty years' service. The staff that currently supported the applications being the original designers and developers in many situations. The applications provided had high levels of functionality and cross-integration. They were also integrated with the OM business processes through a series of process and Lean Value Stream mapping exercises, resulting in a complex system based landscape.

As shown in Table 1 the key OM-AS interface issues arising had commonality across all three OM-AS sub groups These issues were coded as operational and strategic in nature (key areas 1 and 2 in Table 1). Operational problems in Table 1 (Key Area 1) for all three sub groups included lack of Lean-based standardised procedures (or Kos) leading to excessive cycle times and replication of resources, large variation and variety in OM project requests due to changing OM requirements; a culture of inward performance measurement rather than customer pull, a poor existing record of Lean service delivery performance measures, and excessive measurement of more easily quantified internal Lean PMs (e.g. volume and duration of enquiries), consistent with Biege et al (2012) and Jaaskelainen et al (2012). Perceived strategic problems, as shown in Table 1 (Key Area 2), included translation rather interpretation of product Lean PMs. There was a technology push rather than service or customer pull focus, lack of staff training and incentives to align with customer (OM) Lean PMs. Moreover, there was a lack of senior management understanding and buy-in to more customer-based Service Level Agreements (SLA KOs) and the need for joint Lean based Balanced Scorecards (BSCs). The OM-AS staff operating within the OM-AS interface space had developed unique 
capabilities in business interpretation and in working in cross functional teams with managers, engineers and operations employees. However they had not integrated these skill sets into a more systems and customer focused approach to OM-AS transformation of the KOs, which ultimately limited their understanding and effectiveness, as suggested by Gibbons et al (2012) and Liker and Morgan (2006). OM-AS staff, usually with many years of experience of silobased working, instinctively protected their knowledge base resources. There was a perceived reluctance to share resource across the three OM-AS sub-groups based on customer-pull in case of sudden variation in demand where an OM-AS sub team would be left without $100 \%$ availability of their application expert(s). This limitation resulted in Lean waste due to scarce resources being allocated to support smaller projects for long periods of time when they could have been better utilised on larger strategic projects on a customer demand basis. Table 1 (Key Area 2) also shows that lack of appropriate tailoring of the legacy I.T. Systems was a strategic issue. The current level of tailoring has ensured that these systems have not been prioritised for replacement by the new Strategic Solutions team at Group level. However, the legacy systems were based on aging technology that could not meet the needs of the increased complexity and variety of OM requests. The focus groups and the first workshop showed that strong collaboration solutions were required with the application of newer technologies and more indepth understanding of Lean customer pull factors, as suggested by Biege et al (2012) and Jaaskelainen et al (2012).

It was in the interests of the Case Organisation to develop the OM-AS staff with the Lean skills and experience required to play a role in the implementation and support of the new strategic systems (albeit initially based on the production-based LAES impetus). This change required increased efficiency, with the need to free OM-AS resources from support activities to participate in group projects in a Lean customer pull manner. Becoming efficient so that they 
could continue to support their legacy infrastructure and also transition resources over onto these critical projects was a significant challenge to the OM-AS team. In relation to the development of the KO of Lean PMs there was a tendency to rely on the default of existing production-based Lean PMs (Liker, 2004 and Staats et al, 2011). Table 1 (key area 4) shows that the operations and strategic interface issues were reflected in each of the three sub teams. These issues formed the basis of the process to identify key areas for improvement in the Lean Value Stream.

Table 1 (Key Area 4) also shows how the OM-AS sub groups perceived Lean wastes. These classifications as part of the $\mathrm{KO}$ transformation process tended to use manufacturing language (due to the production-based Company-wide LAES legitimacy; Suchman, 1995). Examples were. rework, defects, transportation, and lack of asset use. However there were some examples (as shown in Table 1) of more inclusive language for waste (e.g. processing time; time waiting for customer, workflow, lack of multitasking and inadequate testing (Arlbjørn and Freytag, 2013; Gibbons et al, 2012), which were further transformed and leveraged in the second workshop and the experiments. The concept of Failure-Demand relating to waste from failure to address the customer requirements or over producing beyond the customer specification (Table 1, Key Area 5) proved more difficult to grasp due to the lack of Lean customer pull PMs, consistent with Seddon’s (2008) findings.

The perceptions from the OM-AS staff interviews showed that they rated the service as responsive and flexible with employees who understood the business processes and operations and who drew from this experience to deliver highly customised solutions. In particular examples were given of the business service requestor going to their usual OM staff member that they had always dealt with on a relationship basis leading to rapid problem resolution. 
However, there was no formal evaluation using systematic Lean PMs to demonstrate if efficiency and value was obtained at a strategic level and whether it was communicated effectively to key decision makers.

\subsection{OM-AS provision current and future state Lean Value Stream mapping and opportunities (covering Phase 2 and primarily RQ2).}

The two sequential workshops in phase 2 were held to develop a more detailed analysis of the transformation of the KOs of current and future state Lean Value Stream maps resulting in the following findings to address RQ2 and RQ3. The current state OM-AS provision Lean Value Stream Map i.e. consistent with Gibbons et al's (2012) mapping method, was developed through Phase 1 and Phase 2 in workshop 1.

This process started with the receipt of a request/demand from an internal customer for a fix or enhancement to an I.T. system and ends with the acceptance of the working I.T. solution by the customer or the rejection of the request (Table 1). To support this value stream mapping the researchers had already extracted data from the OM-AS and organisation records on Lean PMs such as average elapsed times and average lead times, which could be used during the mapping. The process was highly interactive involving everyone in a consensus building approach as suggested by Gasson (2005) and Swan et al (2007) and aided by option-finder selection technology. The following limitations of the current state were found:

- OM and AS staff had too many different demands at one time resulting in frequent interruptions, task switching, a lack of focus and high levels of frustration.

- There was limited standardisation of work.

- Resource scheduling was overly complex because OM and AS staff worked on multiple projects simultaneously as well as participating on support rotas within their team. 
- The dynamic nature of large projects required frequent variations to work plans and resource assignments.

An analysis of the workload within the OM-AS team showed a large variation in service requests (as noted by Jaaskelainen et al, 2012). There were 22 projects were currently on-going, 14 demands were underway (work in progress), 37 demands were in backlog and 130 demands were in the approval process (i.e. the acceptance of requests as being legitimate requirements). Based on the level of resources available, OM and AS staff members were assigned to multiple demands and projects at the same time. On average only $44 \%$ of demands were delivered on time, $85 \%$ of demands in the approval process had been there for more than 16 weeks and $72 \%$ of projects were in deficit in terms of significant schedule, cost or resource. The average ratio between value added time and lead time was only $14 \%$.

To achieve improvements the OM-AS interface team developed the transformed KO of the future state Lean Value Stream map, consistent with Gibbons et al (2012) approach, in workshop 1 - Figure 4. 


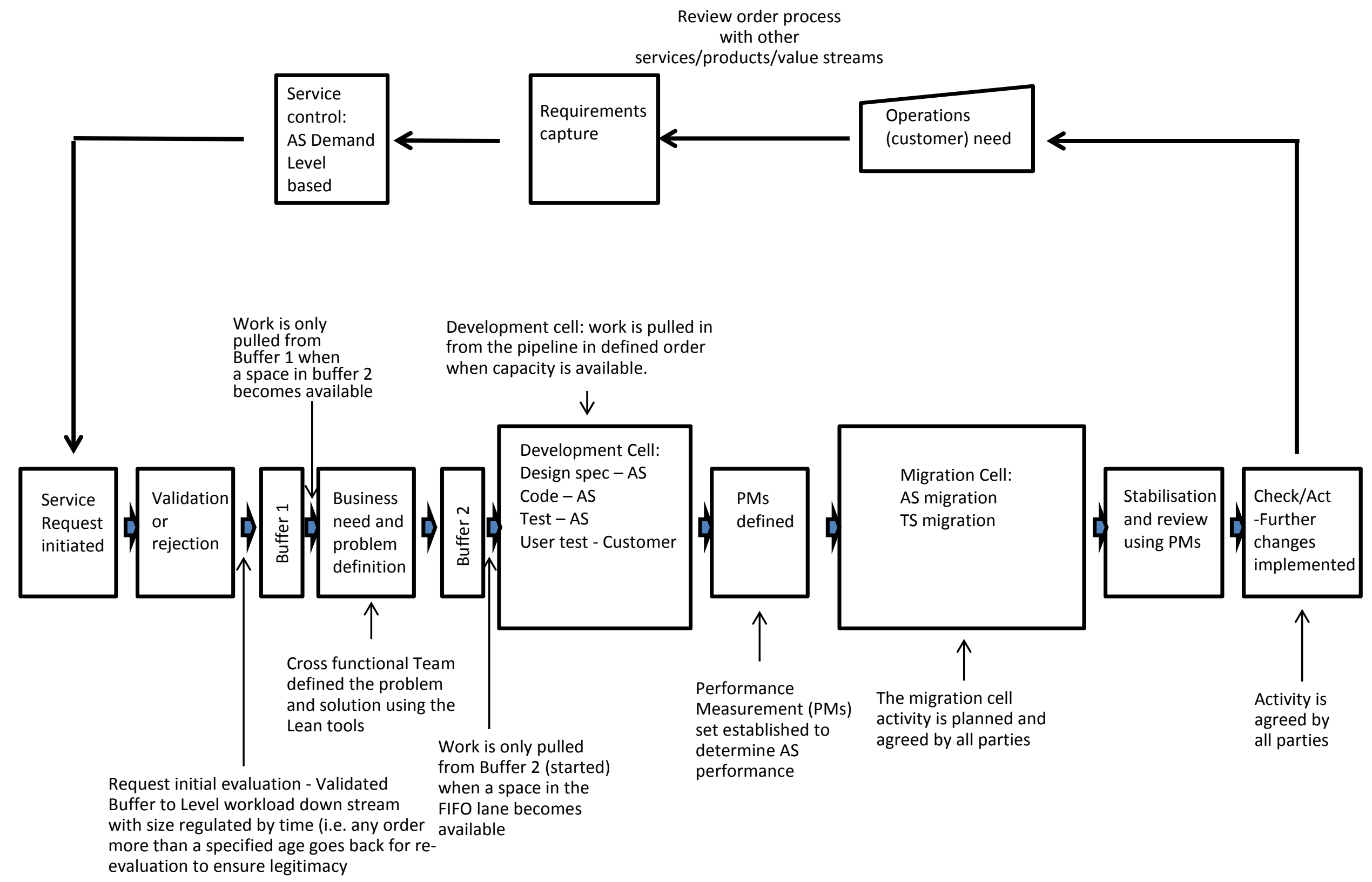

Figure 4 - Future state OM-AS provision Lean Value Stream Map 
The following main changes were recommended to establish this future state map:

1 Buffers were introduced in the process to level out the workload downstream. The size of the first buffer was be regulated by time. Anything older than a specified age would go back for re-evaluation to ensure that the requirement was still legitimate;

2 Work would only be pulled from buffer one when there was a space in buffer two;

3 A joint OM-AS team would define the problem using Lean problem solving techniques and would only proceed to buffer two whenever the full requirements and the solution were clearly defined, by both OM and AS staff and when there was an available space in buffer two;

4 A third and final buffer, the First In First Out (FIFO) Lane, would be controlled by a limited number of demands that had been prioritised in buffer two based on urgency;

5 Work would only get pulled into the development cell whenever a dedicated resource was available to complete the work and everything was in place including customer readiness; and

6 A final Check/Act phase would be introduced using the Plan Do Check Act (PDCA) cycle to confirm that the value had been realised for the customer.

In order to run a number of trials or experiments through the new Future State process the researchers obtained some development resources within the OM-AS MAXIM sub team dedicated to the experiment for its duration. The MAXIM sub team was the second largest of the OM-AS sub teams focusing on the MAXIM system that supports manufacturing processes.

\subsection{Experiment 1 - Flow Experiment - RQ2}

Five demands were passed through the new future state OM-AS provision Lean Value Stream map (Figure 4) these demands were OM requests for I.T. development work and represented 5 variations on the continuum ranging from a fix to a problem with an I.T. system through to the 
need for an more involved enhancement to an I.T. system). The following results (see Table 2) were obtained on the ratio between Value Added time and Lead Time (VT/LT) in comparison to a VT/LT of $14 \%$ based on the previous AS provision Lean Value Stream map.

Table 2 - VT//LT Ratio

\begin{tabular}{|l|l|l|l|}
\hline & LT (days) & VT (days) & VT/LT \\
\hline $1^{\text {st }}$ & 43 & 21.5 & $50 \%$ \\
\hline $2^{\text {nd }}$ & 24 & 4 & $17 \%$ \\
\hline $3^{\text {rd }}$ & 14 & 3.5 & $25 \%$ \\
\hline $4^{\text {th }}$ & 7 & 3.5 & $50 \%$ \\
\hline $5^{\text {th }}$ & 9 & 3 & $33 \%$ \\
\hline
\end{tabular}

As seen from Table 2, there was a significant improvement in the 14\% VT/LT ratio estimated in the current State Lean Value Stream map in all the demands, with the exception of the second one (17\%). An analysis of this demand found that the problem lay in not completing the upfront definition of the requirements and the solution correctly, which resulted in the work flowing backwards from the development cell, with increased elapsed time until the issues were resolved. Further training and development of staff in the new Lean Value Streaming approach was required to reinforce these points. Thus, in relation to RQ2 the Lean Value Stream flow based on consistent interpretation of OM-AS Lean PMs (Figure 4; Table 1)was sufficiently promising to enable the researchers to proceed to Experiment 2.

\subsection{Experiment 2 - Failure-Demand Experiment-RQ3}

An initial analysis of demands received over a one year period at an overall OM-AS departmental level was conducted and showed the following breakdown. At an overall OMAS level 27,937 demands were received over a one year period with 52\% (14,555 demands) of these being handled by the OM-AS team in general and 48\% (13,382 demands) being handled by the OM-AS TS (Technical Support) sub-team in particular. This paper addresses 
requests for the OM-AS team in general. Of the sixteen OM-AS units the largest number of demands was received by the Engineering operations unit, representing $56 \%$ of the overall OM-AS demands or 8,120 demands. The second largest number was received by the MAXIM unit, representing 19\% of the overall demands, or 2,716 demands. The remaining $25 \%$ of the demands were received by the remaining fourteen OM-AS categories.

Six of these OM-AS units conducted the initial analysis and two were selected to follow the analysis through to completion of the experiment i.e. the MAXIM and the Engineering operations units. These selection decisions were made on data availability, organisation resource availability and limitations of the research team. The Engineering operations unit analysis, due to the large volumes of calls, was conducted based on password related calls. The findings of the MAXIM team are detailed in Table 3 below, which also shows the results from the six units who completed the analysis.

Table 3 - Value/Non Value demand analysis by participating groups

\begin{tabular}{|c|c|c|c|c|}
\hline Agency & $\begin{array}{c}\text { Calls } \\
\text { Analysed }\end{array}$ & $\begin{array}{c}\text { Value } \\
\text { Added }\end{array}$ & $\begin{array}{c}\text { Non } \\
\text { Value } \\
\text { Added }\end{array}$ & $\begin{array}{l}\text { Non Value } \\
\text { Added \% } \\
\end{array}$ \\
\hline MAXIM & 106 & 14 & 92 & $87 \%$ \\
\hline FATS & 29 & 23 & 6 & $21 \%$ \\
\hline Engineering & 77 & 46 & 31 & $40 \%$ \\
\hline Documentum & 35 & 18 & 17 & $49 \%$ \\
\hline BCS & 16 & 9 & 7 & $44 \%$ \\
\hline CAPP & 40 & 20 & 20 & $50 \%$ \\
\hline
\end{tabular}

The MAXIM sub-team had the second largest number of demands within OM-AS as seen in

Table 3. An analysis of their 2,716 demands was over the one year period. Within the system that captures these demands there was a field for the classification of the demand by the 
MAXIM unit. This field is called the 'demand category' and it is mandatory that this field is completed. However, historically, and prior to these experiments, it had not been used for OM-AS governance or Lean PM. Applying this field to an extract of the demands received by the MAXIM sub-team over the sample one year period showed that there were many different categories (i.e. large variation, Biege et al, 2012 and Jaaskelainen et al, 2012). It is interesting to note that there was a category for 'Failure', where only less than one per cent of the demands were placed in this category showing a lack of recognition of the extent of failure related Lean (consistent with Seddon, 2008; Biege et al, 2012). Based on these results it was decided that a one month sample of this data would be analysed and reclassified based on the criteria for Lean value-added and non-value added from the perspective of the OM customer (Womack and Jones, 2005, Seddon, 2005).

Of the total 176 monthly demands, 78 of these were found to be related to a particular problem involving systems passwords for that month. These demands were not typical of the calls received by the MAXIM unit, and as the Engineering unit were basing their Failure-Demand experiment specifically around password-related demands the MAXIM sub-team decided to exclude these from their analysis as being unrepresentative. The remaining 98 demands were analysed in detail and 85 of the demands (87\%) were classified as 'non-value' demands while only 13 demands (13\%) were classified as 'value' demands using service-based Lean PM terminology. A further analysis of the 85 non-value demands produced a list of fourteen improvement opportunities that could be identified and eliminated. Overall, experiment 2 showed that classification of category data was more difficult and subjective in a Lean OMAS environment due to the high levels of variety in demand (as also suggested by Seddon's (2005) demand failure concept) and the need for knowledge and skills in service based Lean PM in classifying demands with scarce resources. 


\section{Discussion}

There is a lack of research involving linked theory and practice into Lean OM-AS interfaces (Johnston, 2005; Piercy and Rich, 2009; Del-Palacio et al, 2011). In this paper we make a contribution to theory by combining Lean principles (Arlbjorn and Feytag, 2013) with boundary spanning theory (Carlile, 2002, 2004; Gasson, 2005) to explore Lean in the context of the OM-AS interface space. Conceptualising the interface as a space of transformation (building on Levina and Vaast (xxx) enabled the exploration of the interchange within this interface space. The theory in relation to the use of boundary spanning theory helped in identifying key Lean related boundary (knowledge) objects, namely Lean PM sets and Lean Value Stream maps. These KOs met the selection criteria of being malleable and having capacity for transformation at the OM-AS interface (Krafft et al, 2011; Hult, 2011). Thus we make a contribution to theory in relation to Lean in interface areas and to the OM-AS interface space in particular. Moreover, we argue that the transformation of Lean KOs at the interface space can act as an orchestrating process for advancing OM-AS projects in the interface space which represents an additional utility of Lean applicability in an interface context. This contribution is further brought out in relation to each of the three research questions in further elaborating the conceptual framework of Figures 1 and 2.

In relation to RQ1 there was considerable confusion and misuse of resources at both strategic and operational levels across the OM-AS interface as embodied in OM and AS personnel seeking to establish a common language (as summarised in Table 1 and Figures 1 and 2) to form insipient Kos (as suggested by McGivern and Dopson, 2010). This confusion resulted from production based Lean PM terminology initially being translated into the service environment of AS without appropriate contextualisation and consensus building in the OMAS interface space, consistent with the findings of Biege et al (2012), Jaaskelainen et al (2012) 
and Maleyeff (2006). This situation was further exacerbated by the company wide LAES product based view of Lean which was imposed upon the AS and other service departments (Figure 1). The findings suggest that such imposition of uniformity ultimately led to sub optimisation of Lean in in the OM-AS interface due to lack of a common Lean language. Alsmadi et al (2012) calls for contextualisation of Lean- based initiatives from the outset to avoid such mistakes being reinforced by what Suchman (1995) refers to as the legitimation forces of company-wide initiatives (such as the production-based LAES system in the case analysis). Bowen and Youngdahl's (1998) suggestion that Lean acts as a mediating mechanism between product based demands and service delivery is useful however the contextualising of product-based demands within the OM-AS interface space requires substantial time and resources and use of appropriate Lean KOs through a mediated consensus building process to avoid conflict further down the delivery process (Biege et al, 2012; Staats et al, 2011).

In relation to experiment 1 and RQ2 there was evidence from the findings that the OM-AS team developed key mediating Lean boundary (knowledge) objects which included Lean PM sets and Lean Value stream maps, which were transformed over time. The transformation of these KOs became the key orchestrating process for developing the effectiveness of the OMAS interface in achieving project deliverables, consistent with Hult (2011), Alsmadi et al (2012) and Arlbjørn et al (2011). The consensus building process led to the effective development of the future state map with resultant Lean Value Stream improvements within the OM-AS provision. (Figure 4). However, these improvements (e.g. VT/LT rations across longitudinal demand levels) require further exploration in a wider range of scenarios beyond the scope of the present study. One of the biggest benefits to come from the Flow experiment was the introduction of the visibility boards as found by Maleyeff (2006) to support the Future State process. This approach has provided a mechanism to allow the joint teams of OM and AS 
staff within the OM-AS interface space to visualise the Kos in terms of bottlenecks, the priorities and the flow of work and to devise solutions. The experiment in general has been positive in presenting a view of what could be achieved through Lean in the OM-AS interface context leading to a number of follow on Lean improvement projects.

The waste experiment (experiment 2; RQ3) in building on experiment 1 showed the need to address Seddon's (2005) Failure-Demand Lean PM as part of the KO Lean PM sets. The experiment highlighted that the integrity of the KO transformation process for classifying waste relied heavily on the knowledge and experience of the staff carrying out the classification. They required knowledge of Lean concepts and principles interpreted and contextualised in OM-AS interface environments as noted by Arlbjørn et al (2011) and Radnor and Johnston (2013). Moreover due to the high level of variety in the demands received, they also needed to have considerable knowledge of the subject of the demand itself, as noted by Seddon (2005). Thus, considerable OM and AS personnel development would be required to raise the level of Lean knowledge beyond that of standardised production approaches where such development could include using action-learning (Jasaskelainen et al, 2012 and Gibbons et al, 2012).

\section{Conclusions and Recommendations}

In relation to the aim of the paper it is concluded that the use of Lean within the OM-AS interface space needs to be understood from a linked theory and practice perspective to show how it can be managed and improved (Radnor and Johnston, 2013; Staats et al, 2011). We also conclude that the combined use of lean principles and boundary spanning theory provides a useful theoretical basis for exploring OM-AS interfaces in a linked theory and practice manner. In particular lean boundary (knowledge objects) including lean PM sets and Lean Value Stream maps can act of malleable and transformative KOs for orchestrating Lean development in the 
OM-AS interface boundary spanning objects. In relation to RQ1 it is concluded that systematic consensus building over time, as suggested by Swan et al (2007) and McGivern and Dopson (2010), is needed to ensure commonality between AS and OM staff in relation to a shared understanding of Lean constructs and terminology. Without this consensus building the respective knowledge bases of production and Information Systems will fail to realise the synergistic benefits from lean at OM-AS interface. In relation to RQ2 it is concluded that the lean Value Stream map building on Lean PM sets acts as a key transformative process for helping to achieve consensus between OM and AS personnel by providing a common $\mathrm{KO}$ as suggested by McGivern and Dopson (2010) and Hult (2011). Finally in relation to RQ3 it is concluded that the KOs of Lean PM sets and Lean Value Stream maps must have the capability to address Seddon's (2005) concept of Lean Failure-demand due to higher variety of requests within the OM-AS interface space in comparison to other production environments.

Three recommendations for practice are suggested. First, OM and AS staff working in the interface space require training, development and experience in the use of Lean terminology and its differences across OM and AS. They also require training on how to effectively develop consensus building in team situations to transform Lean Kos effectively. A possible approach could include a linked programme of discrete training sessions and action learning in a real time situation. Rather than simple translation from operations, Lean KOs should be contextually grounded for OM-AS interface environments which could reduce the danger of complying with irrelevant production-based Lean PMs and the misuse of scarce resources.

In terms of recommendations for areas of further study, it is suggested that the theoretical approach of combing Lean principles and boundary spanning theory could be applied to other 
OM-AS inter organisational interface spaces. Such studies could further enrich our understanding of the influencing factors involved in the transformation process. Moreover there is potential for applying the theoretical approach to intra organisational interfaces.

\section{References}

Alsmadi, Majed, Ahmad Almani and Rula Jerisat. 2012. "A Comparative Analysis of Lean Practices and Performance in the UK Manufacturing and Service Sector Firms." Total Quality Management \& Business Excellence 23 (4): 381-396. doi 1019238079.

Arlbjørn, Jan S. and Per V. Freytag. 2013. "Evidence of Lean: A Review of International Peer-Reviewed Journal Articles." European Business Review 25(2):174-205. doi 1302646558.

Arlbjørn, Jan S., Per V. Freytag and Henning de Haas. 2011. "Service Supply Chain Management." International Journal of Physical Distribution \& Logistics Management 41 (3): 277-295. doi 861089197.

Baglieri, Daniela, Maria C. Cinici and Vincent Mangematin. 2012. "Rejuvenating Clusters with 'Sleeping Anchors': The Case of Nanoclusters." Technovation 32(3):245-256. doi 963343578.

Barratt, Mark, Thomas Y. Choi and Mei Li. 2011. "Qualitative Case Studies in Operations Management: Trends, Research Outcomes, and Future Research Implications." Journal of Operations Management 29(4):329-342. doi 866084137.

Biege, Sabine, Gunter Lay and Daniela Buschak. 2012. "Mapping Service Processes in Manufacturing Companies: Industrial Service Blueprinting." International Journal of Operations \& Production Management 32 (8): 932-957. doi 1023825091.

Bortolotti, Thomas and Pietro Romano. 2012. "'Lean First, then Automate': A Framework for Process Improvement in Pure Service Companies. A Case Study." Production Planning \& Control 23 (7): 513-524. doi 1016476321.

Bowen, David E. and William E. Youngdahl. 1998. "Lean" Service: In Defense of a Production-Line Approach." International Journal of Service Industry Management 9 (3): 207-225. doi 233646062.

Carlile, Paul R. 2002. "A Pragmatic View of Knowledge and Boundaries: Boundary Objects in New Product Development."Organization Science 13(4):442-455. doi 213834791.

Carlile, Paul R. 2004. "Transferring, Translating, and Transforming: An Integrative Framework for Managing Knowledge Across Boundaries." Organization Science 15(5):555-568. doi 213832926.

Coughlan, Paul and David Coghlan. 2002. "Action research for operations management", International Journal of Operations \& Production Management 22 (2): 220-240. doi 1443570210417515

de Jong, Jeroen,P.J. and Mark Freel. 2010. "Absorptive Capacity and the Reach of Collaboration in High Technology Small Firms."Research Policy 39(1):47-54. doi 223238473. 
Del-Palacio, Itxaso, Francesc Sole and Jasmina Berbegal. 2011. "Which Services Support Research Activities at Universities?" The Service Industries Journal 31 (1): 39-58. doi 846926089. doi 210513195.

Eisenhardt, Kathleen M. 1989. "Building Theories from Case Study Research." Academy of Management Review 14 (4): 532-550. doi 210938650.

Gasson, Susan. 2006. "A Genealogical Study of Boundary-Spanning IS Design." European Journal of Information Systems15(1):26-41. doi 3000594.

Gibbons, Paul M., Colin Kennedy, Stuart C. Burgess and Patrick Godfrey. 2012. "Developing an Asset Management Value Improvement Model (a-VIM) Approach for an Airport Operational Engineering Environment." The International Journal of Quality \& Reliability Management 29 (7): 819-841. doi 1030152103.

Greve, Arent and Janet W. Salaff. 2003. "Social Networks and Entrepreneurship." Entrepreneurship Theory and Practice 28(1):1-22. doi 213807674.

Hellstrom, Tomas, Johan Eckerstein and Alexander Helm. 2001. "R\&D Management through Network Mapping: Using the Internet to Identify Strategic Network Actors in Cooperative Research Networks." R \& D Management 31(3):257-263. doi 233088221.

Hines, Peter, Matthias Holwe and Nick Rich. 2004. "Learning to Evolve: A Review of Contemporary Lean Thinking." International Journal of Operations \& Production Management 24 (9): 994-1011. doi 232364114.

Hult, G. T. 2011. "Toward a Theory of the Boundary-Spanning Marketing Organization and Insights from 31 Organization Theories." Academy of Marketing Science.Journal 39(4):509-536. doi 881696346.

Jääskeläinen, Aki, Harri Laihonen, Antti Lönnqvist, Miikka Palvalin, Virpi Sillanpää, Sanna Pekkola and Juhani Ukko. 2012. "A Contingency Approach to Performance Measurement in Service Operations." Measuring Business Excellence 16 (1): 43-52. doi 928743702.

Johnston, Robert. 2005. "Service Operations Management: Return to Roots." International Journal of Operations \& Production Management 25 (12): 1278-1297. doi 232337452.

Johnston, T., Clark, G. and Shulver, M. (2012), Service Operations Management: Improving Service Delivery, Prentice Hall, London.

Kellogg, Katherine C., Wanda J. Orlikowski and JoAnne Yates. 2006. "Life in the Trading Zone: Structuring Coordination Across Boundaries in Postbureaucratic Organizations." Organization Science 17(1):22-44. doi 213832342.

Krafft, Jackie, Francesco Quatraro and Pier P. Saviotti. 2011. "The Knowledge-Base Evolution in Biotechnology: A Social Network Analysis." Economics of Innovation and New Technology 20(5):445-475. doi 878642666.

Letti, C., C. Hienerth and H. Gemuenden. 2008. "Exploring how Lead Users Develop Radical Innovation: Opportunity Recognition and Exploitation in the Field of Medical Equipment Technology." IEEE Transactions on Engineering Management 55(2):219233. doi 195642855.

Levina, Natalia and Emmanuelle Vaast. 2005. "THE EMERGENCE OF BOUNDARY SPANNING COMPETENCE IN PRACTICE: IMPLICATIONS FOR 


\section{IMPLEMENTATION AND USE OF INFORMATION SYSTEMS1." MIS}

Quarterly 29(2):335-363. doi 218130637.

Liker, J.K. (2004), The Toyota Way: 14 Management Principles from the World's Greatest Manufacturer, McGraw-Hill, New York.

Liker, Jeffrey K. and James M. Morgan. 2006. "The Toyota Way in Services: The Case of Lean Product Development." The Academy of Management Perspectives 20(2):5-20.

Lyons, Andrew C., Keith Vidamour, Rakesh Jain and Michael Sutherland. 2013. "Developing an Understanding of Lean Thinking in Process Industries." Production Planning \& Control 24(6):475-494, doi 1351355764.

Maleyeff, John. 2006. "Exploration of Internal Service Systems using Lean Principles." Management Decision 44(5):674-689. doi 12086213.

Marr, Bernard. and Stephen Glenn. 2004. "Performance management in call centers: lessons, pitfalls and achievements in Fujitsu Services", Measuring Business Excellence 8 (4): 55-62. doi 13683040410569415.

Martínez-Jurado, Pedro,J. and Jos Moyano-Fuentes. 2014. "Key Determinants of Lean Production Adoption: Evidence from the Aerospace Sector." Production Planning \& Control 25(4):332345). doi 1469828121.

McGivern, Gerry and Sue Dopson. 2010. "Inter-Epistemic Power and Transforming Knowledge Objects in a Biomedical Network."Organization Studies 31(12):16671686. doi 840745461.

Parry, Glenn., John Mills and Celine Turner. 2010. "Lean competence: integration of theories in operations management practice", Supply Chain Management 15 (3): 216-226. doi 13598541011039974.

Peltier, James W. and G. M. Naidu. 2012. "Social Networks Across the SME Organizational Lifecycle." Journal of Small Business and Enterprise Development 19(1):56-73. doi 923391839.

Piercy, Niall and Nick Rich. 2009. "Lean Transformation in the Pure Service Environment: The Case of the Call Service Centre." International Journal of Operations \& Production Management 29 (1): 54-76. doi 232352668.

Pratt, Michael G. 2009. "For the lack of a boilerplate: Tips on writing up (and reviewing) qualitative research". Academy of Management Journal 52 (5): 856-862. doi 99815708.

Radnor, Zoe and Robert Johnston. 2013. "Lean in UK Government: Internal Efficiency Or Customer Service?" Production Planning \& Control 24 (10-11): 903-919. doi 1433905983.

Riezebos, Jan, Warse Klingenberg and Christian Hicks. 2009. "Lean Production and Information Technology: Connection Or Contradiction?" Computers in Industry 60 (4): 237-247. doi 235776646.

Robinson, George and Clive Morley. 2006. "Call Centre Management: Responsibilities and Performance." International Journal of Service Industry Management 17 (3): 284300. doi 233653121.

Seddon, J. 2005. Freedom from Command and Control, Vanguard Education, London.

Seddon, John. 2008. Systems Thinking in the Public Sector: The failure of the reform regime and a manifesto for a better way, Triarchy Press, London.

Spithoven, André, Bart Clarysse and Mirjam Knockaert. 2010. "Building Absorptive Capacity to Organise Inbound Open Innovation in Traditional

Industries." Technovation 30(2):130-141. doi 195863145. 
Staats, Bradley R., David J. Brunner and David M. Upton. 2011. "Lean Principles, Learning, and Knowledge Work: Evidence from a Software Services Provider." Journal of Operations Management 29 (5): 376-390. doi 866083557.

Suárez-Barraza, Manuel,F. and Juan Ramis-Pujol. 2010. "Implementation of Lean-Kaizen in the Human Resource Service Process." Journal of Manufacturing Technology Management 21 (3): 388-410. doi 208172212.

Suárez-Barraza, Manuel,F., Tricia Smith and Su Dahlgaard-Park. 2012. "Lean Service: A Literature Analysis and Classification." Total Quality Management \& Business Excellence 23 (3-4): 359-380. doi 19235959.

Suchman, Mark C. 1995. "Managing Legitimacy: Strategic and Institutional Approaches." Academy of Management Review 20(3):571-610. doi 210941848.

Swan, Jacky, Mike Bresnen, Sue Newell and Maxine Robertson. 2007. "The Object of Knowledge: The Role of Objects in Biomedical Innovation." Human Relations 60(12):18091837. doi 231528253.

Swank, Cynthia K. 2003. "The Lean Service Machine." Harvard Business Review, 10, 123-139. doi 227777502.

Vowles, Nicole, Peter Thirkell and Ashish Sinha. 2011. "Different Determinants at Different Times: B2B Adoption of a Radical Innovation." Journal of Business Research 64(11):11621168. doi 900918991.

Wang, L., Ming, X.G., Kong, F.B., Li, D. and Wang, P.P. 2012. "Focus on implementation: a framework for Lean product development", Journal of Manufacturing Technology Management 23 (1): 4-24. doi 17410381211196267.

Womack, J. and Jones, D.T. (1996), Lean Thinking: Banish Waste and Create Wealth for Your Corporation, Simon and Schuster, New York, New York, NY.

Womack, James P. and Daniel T. Jones. 2005. "Lean Consumption." Harvard Business Review, 03, 59-68. doi 227816288.

Yin, R.K. (2009), Case Study Research: Design and Methods, Sage Publications, Beverly Hills, California. 


\section{Appendix No 1. Semi Structured interview format}

The issues shown below were the main interview guide for both AS and OM actors. However the actual interview of ten discussed extensions of these issues and not in the order listed due to its semi structured nature.

1. Describe your experience in your knowledge base (OM or AS).

2. Describe your experience of working in the OM-AS interface.

3. Can you discuss your perceptions, understanding and experience of Lean?

4. Describe your experience in working in the OM-AS interface.

5. What are the challenges in working in the OM-AS interface?

6. What sorts of projects are involved in the OM-AS interface?

7. How is Lean used in the OM-AS interface

8. What are the barriers and enablers to using lean in the OM-AS interface?

9. Is Lean a useful concept in the OM-AS interface?

10. How is consensus reached among the different members of the OM-AS interface?

11. How does lean principles and constructs help in establishing consensus and progressing OM-AS projects?

12. What is your understanding of the Lean Value Stream map in the OM-AS interface?

13. What is your understanding of Lean performance measurement in the OM-AS interface?

14. Discuss and other relevant issues based on working in the OM-As interface. 
